IRA-International Journal of Management \& Social Sciences

ISSN 2455-2267; Vol.05, Issue 01 (2016)

Pg. no. 47-53

Institute of Research Advances

http://research-advances.org/index.php/RAJMSS

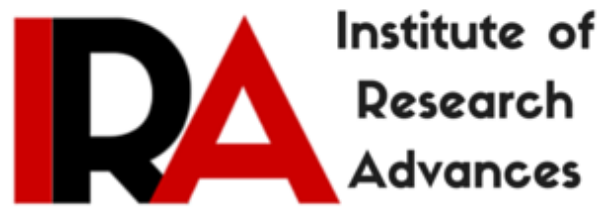

\title{
"Pushed Off to the Side": A Study on the Socio-Economic Dynamics of Marginalization and the Elderly Women
}

\section{Swagatika Samal}

Assistant Professor (Social Work),

Department of Anthropology, Sambalpur University, India.

Type of Review: Peer Reviewed.

DOI: http://dx.doi.org/10.21013/jmss.v5.n1.p6

\section{How to cite this paper:}

Samal, S. (2016). "Pushed Off to the Side": A Study on the Socio-Economic Dynamics of Marginalization and the Elderly Women. IRA-International Journal of Management \& Social Sciences (ISSN 2455-2267), 5(1), 47-53. doi:http://dx.doi.org/10.21013/jmss.v5.n1.p6

(C) Institute of Research Advances

\section{(c) EY-NC}

This work is licensed under a Creative Commons Attribution-Non Commercial 4.0 International License subject to proper citation to the publication source of the work.

Disclaimer: The scholarly papers as reviewed and published by the Institute of Research Advances (IRA) are the views and opinions of their respective authors and are not the views or opinions of the IRA. The IRA disclaims of any harm or loss caused due to the published content to any party. 


\begin{abstract}
Ageing is an inevitable and inexorable process in life. In India, the population of the elderly is growing rapidly and is emerging as a serious area of concern for the government and the policy planners. Now a days with changing social structure and values, elderly in general and the elderly women in particular experience difficulty in their everyday life. Growing social complexities and the structural discrimination against these people is resulting in their vulnerability to physical, economic, psychological, and emotional abuse. Physical segregation of their settlements is common in many cases forcing them to live in the most unhygienic and inhabitable conditions. All these factors affect their social and health status, access to healthcare and finally their quality of life. Presence of powerful social differentiation, absence of social safety net and the community support system for these women pervade them into vulnerability and further marginality. Studies of showed elderly women, especially widows are more likely than elderly men to live alone, more likely not to have source of income, more likely not to be in contact with children and close members of the family, and more vulnerable financially, socially and culturally. Moreover, they live a life of isolation and trauma.

The present paper aims to put some light on various dimensions of marginality \& vulnerability of the elderly women, its socio-economic dynamism and at the end it tries to suggest some remedial measures against the discussed issues. Data for the study has been collected from the older women of Budharaja, Danipali, Fatak, Mudipada, Sakhipada, and Khetrajpur areas of Sambalpur town through formal \& informal interviews, case studies, and observation methods.
\end{abstract}

\title{
INTRODUCTION
}

Old age represents its own unique problems but the needs and problems of the elderly vary significantly as per their age, socio-economic status, health status, and their living status etc. (Raju, 2002). The informal support systems of family, kinship and community in traditional Indian society are the major means of providing social security to its senior members. These traditional safety nets have been greatly influenced by the impact of so called urbanization, industrialization and modernization on our society. The gradual nuclearization of the joint family, erosion of family values, changes in care structure, migration of youth from rural to urban areas and from cities to megacities for better jobs and employment opportunities, and increasing participation of women in the workforce are some of the responsible factors contributing to the marginalization of elderly people in India. Consequently, majority of the elderly in both the urban and rural communities lead isolated life and maintain the intimacy with their children from a distance (Kumar, 1999).

Elderly or old age consists of ages nearing or surpassing the average life span of human beings. The 'National Policy on Older Persons' adopted by the Government of India in January, 1999 defines 'senior citizen' or 'elderly' as a person who is of age 60 years or above. The elderly population (aged 60 years or above) in our country account for 8.0 per cent of total population (Census of India, 2011) and there seems a steady increase in the size of the elderly population i.e., from 6.0 per cent in 1991 to 7.2 per cent in 2001 and 8.0 per cent in the year 2011. This implies that both the share and size of elderly population is increasing over time and the Ministry of Statistics and Programme Implementation, GOI has projected that India would have an increase in the size of the elderly population with 12.4 per cent of its total population by the year 2026 (MoSPI, 2011).

Traditionally, in India elderly have had a respectable place among almost all communities. Elderly women specifically were enjoying quite respectable position in the families. But, today the contemporary ground realities vary from this fact. With population ageing and fast changing socio-economic circumstances, status of elderly persons particularly elderly women in their respective families and communities has changed. Many instances can be found in our society where even human rights of older women are at stake. Today old women have restricted social interaction, limited earning possibilities, 
several medical complications, emotional isolation from their fellow beings, very limited knowledge or awareness of their legal rights and natural reluctance to seek justice. Being women, in our society due to socio-cultural factors, they are forced to live with several restrictions. Hence they find themselves marginalized and isolated most of the time.

In many Indian communities women are treated as second class citizens. Being old, the elderly women have more critical problems than the elderly men. As women live longer than men, most of them have to live a life of a widow in their silver years. In old age, elderly women face an emotional void in their life. This is so because in India they normally lead a family-centric life since their childhood. Their small world revolve around their families; and when they get old they get sidelined by the same family which is clearly mentioned in the title of the paper - "Pushed off to the side" because it no longer requires their services or they are not fit enough to serve family interests. There are instances of 'crisis in caring' for the elderly women in our society due to transition in family structure, generation gap and change in the role of women in family and society (Prakash, 2004). Old age itself thus is associated with many physiological, economic, emotional and interpersonal facets affecting the social functioning and wellbeing of the elderly women in various ways.

Although there exists many laws and programmes for the protection and empowerment of women including various gender budgeting schemes and the National Policy on Women Empowerment, 2001 in our country, these initiatives hardly focus on old age issues of old women (Balagopal, 2009). As a result, elderly women lead a marginalized life and many of them live a neglected and miserable life.

\section{OBJECTIVES OF THE STUDY}

The study has been conducted to assess the situation of older women in the urban set-up with the following objectives:

- To understand the dimensions of marginality \& vulnerability of the elderly women

- To analyze responsible socio-economic dynamics of miserable living conditions of older women in the study area and

- To suggest or recommend some specific points in the line of issues pertaining the vulnerable elder women.

\section{METHODOLOGY}

Data for the study has been collected from the older women of Budharaja, Danipali, Fatak, Mudipada, Sakhipada, and Khetrajpur areas of Sambalpur town by administering interview schedules, informal interviews, case studies, and observation methods. Under the study, data were collected from randomly selected 50 older women of the selected areas.

\section{MAJOR FINDINGS}

The findings of the study reveal the social and economic aspect of the marginalized elderly women in the study area only. It was observed that the majority of the elderly women were living miserable life conditions which need proper intervention.

\section{Spouse status}

As per the study 48.0 per cent of elderly women interviewed were found widowed. Only 52.0 per cent of the older women were leading a life of married women. Cases of unmarried older women, divorce and remarriage among older women were not found.

During the study, it was observed that for women in India married life matters most in their life even in old age. Death of their husbands brings sea of sorrows for the female senior citizens. It is commonly accepted and valued by the average Indian woman that she wanted to die before her husband's death being 'suhagan' and she wanted to lead a married life throughout her life. Whereas, a widow in Indian 
society is called as 'unfortunate' (Abhaagan) and thus leading a more vulnerable state of life. For a widow, the society put forth many restrictions on their social interaction and living style. Even they are not allowed to be a part of any auspicious occasions. In our study it was found that death of husband has its own implication on the status of the elderly women in the family. With loss of husband most of the widows have lost the status they were enjoying previously. They are not respected by the family members having a secondary status to the males in the family. Their needs are never heard by the children, and specifically their material requirements are not taken care of properly. They feel that with declining physical abilities to work, they have lost their importance in the family being a burden on the family members.

\section{Educational status of elderly women}

Since education plays an important role in determining of living conditions of any individual, educational abilities of older women were also assessed under the study. The study found that 68.0 per cent older women found illiterate, 10.0 per cent just literate and only 22.0 per cent said that they are educated.

\section{Family set up}

Under the study (Table no. -1), it was found that 8.0 per cent older women were living alone in their houses. All of them were widow and their children were living at distance places far from them. A majority of the older women i.e., 46.0 per cent were found living with their aged husbands only and 26.0 per cent were found living with spouse and married children. Most of cases, they were living with their son, daughter- in-law \& children, daughter, etc. The data represents the changing family structure in urban settings where we found many children leave their parents alone in their home and shift to other places for better job opportunities. In such cases it was mostly observed that due to responsibility of their jobs, their children and their education, they cannot visit their parents frequently and take proper care of the ageing parents as expected by many Indian elderly. Thus the situations lead to a change in family structures in cities that we found either the elderly live alone (in case of death of spouse) or live with the ageing spouse only.

Table No. 1: Family set up of the elderly women

\begin{tabular}{|c|c|c|c|}
\hline Sl. No. & Living Arrangement & Sample & \% \\
\hline 1 & Living alone & 4 & $\mathbf{8 . 0}$ \\
\hline 2 & With spouse only & 23 & $\mathbf{4 6 . 0}$ \\
\hline 3 & $\begin{array}{c}\text { with spouse and married } \\
\text { children }\end{array}$ & 13 & $\mathbf{2 6 . 0}$ \\
\hline 4 & $\begin{array}{c}\text { With married children only } \\
\text { unmarried children }\end{array}$ & 8 & $\mathbf{1 6 . 0}$ \\
\hline 5 & Total & $\mathbf{5 0}$ & $\mathbf{1 0 0 . 0}$ \\
\hline
\end{tabular}

Source: Field survey, 2011-12.

\section{Status of elderly women in Family}

The patriarchal family system in Indian society does not allow a woman to head the family. As a result we hardly get women heading their family. Due to longer life span in comparison to older men, and the age difference of marriage in case of a male and female in India, old women were found to be the senior most in many families, but they were mostly depend upon other members in family matters, as they lack financial intelligence and or independence. In the study, it was found that more than a half of older 
women (56 per cent) responded of being marginalized as they are not getting proper respect and concern from their family members and other people. In few cases (16.0 per cent) women were found to heading their respective families, that's why they were generally respected in their families. 28.0 per cent elderly women agreed that they receive due respect and regard from most of their family members.

\section{Relationship of elderly women with their family members}

Almost 54.0 per cent older women said that their relationship with their son/s is affectionate whereas 36.0 per cent older women were not happy with their relationship with them. 32.0 per cent of older women admitted that their relationship with their daughter/s-in-law was not so affectionate. More than 3/4th elderly women living in any kind of family set up liked their relationship with their grandchildren.

\section{Financial status of elderly women}

With regard to the financial status of the respondents, it was found that 64.0 per cent older women had exactly no source of monthly income. They are dependent on their husband and or children for fulfillment of the economic needs. 22.0 per cent poor elderly women were getting old age/widowhood pension. 32 per cent older women were found living in very moderate monthly income group of Rs. 1000/- - Rs. 5000/-. It was also found that more than $2 / 3^{\text {rd }}$ older women had no land/house property entitles in their names. To meet their expenses 28.0 per cent older women were found to be involved in household chores and/or petty business (small shop, vending etc.) 30.0 per cent older women were not found engaged in any kind of work for frequent illness. 42.0 per cent elderly women admitted that they had no work/opportunities to do, hence they sit idle at their home.

With changed socio-economic scenario, disintegration of joint family system, emergence of small and nuclear families and ever-increasing life span in old age, financial requirements of older women have increased dramatically. In absence of all-inclusive social security schemes, elderly women are facing severe financial crisis in old age. The study finds, only 28.0 per cent elderly women were found selfdependent and 64.0 per cent were dependent on their husband's pensions and on their children, so far as their financial needs are concerned. Ironically, 4.0 per cent elderly women were having no such support and dependent on the mercy of their neighbours.

\section{Health Status of elderly women}

In the study, overall health conditions of older women were found not so critical as most of them belong to 65-75 age group. 34.0 per cent elderly women were found in good health even at old age. 48.0 per cent elderly women were suffering from various health related problems such as blood pressure, diabetes, joint pain, digestive disorder, eye ailments, and other common ailments of old age. It was also found that 12.0 per cent older women were in bedridden condition and found disabled physically.

Ironically, it was found that there were 28.0 per cent elderly women who had not been admitted in any hospital for treatment so far in their old age. 52.0 per cent older women got admitted from 1-5 times and 20 per cent elderly women needed to get admitted more than 5 times.

\section{Life satisfaction in Old Age}

74.0 per cent older women opined that in their old age they felt that they were not satisfied with their lives or not satisfied with events that are happening at this life stage. Regarding the reasons for such life dissatisfaction as responded by the elderly women were illness, social isolation, acute financial problem, unsuccessful children/grandchildren, no family support in need, and degrading interpersonal relationships. 
Table No. 2: Life satisfaction of the elderly women

\begin{tabular}{|c|c|c|c|}
\hline Sl. No. & Life satisfaction status & Sample & $\%$ \\
\hline 1 & Satisfied & 13 & $\mathbf{2 6 . 0}$ \\
\hline 2 & Dissatisfied & 37 & $\mathbf{7 4 . 0}$ \\
\hline \multicolumn{2}{|c|}{ Total } & $\mathbf{5 0}$ & $\mathbf{1 0 0 . 0}$ \\
\hline
\end{tabular}

Source: Field survey, 2011-12.

\section{Awareness of the elderly women towards their rights}

Vulnerability of the Indian women is very much common in Indian society as the women hold a secondary status to the men and the related gender biasness in many aspects of life. In such conditions being older adds double vulnerability to the women. Now days, they have become soft target of wrong doers as we find the crime rate against elderly staying alone (without children) is increasing gradually. Specifically, as dependent gender, they hardly complain for anything. Due to illiteracy, poverty, lack of awareness about their rights, less exposure to mainstream of society and their social and cultural background often their rights are violated. In the study, a majority (76.0 per cent) of the elderly women opined that they are not aware about their rights. These women had virtually no knowledge of women rights or elderly rights, due to illiteracy or lack of exposure to the outer world. They have been facing serious discrimination with respect to their rights. They are neglected, abused and mistreated. When questions were asked about harassment/elder abuse and mistreatment with the elderly women, 66.0 per cent agreed that they were being abused and their needs were not taken care of. Surprisingly, 48.0 per cent cases of abuse were found made by their own family members. Under the study observation method was used to find the living conditions of respondents. It was found that 52.0 per cent elderly women were living in inhuman conditions which include their clothes, living place, surroundings, food, health condition, etc.

\section{The common problems of elderly women}

When asked about the common problems the elderly women have been facing in old age, they opined that they were having issues like neglected by family members and relatives, restricted mobility, isolation, financial problems, poor access to health service and care, confined to bed, disability, less respect, less food, insecurity, and unsafe, etc.

\section{SUGGESTIONS}

In order to ensure a minimum standard of living, a respectful life, more comfortable and healthy environment for the senior citizens and the elderly women specifically, the responsibility is bestowed with us to focus on the various issues concerning the elderly women and develop effective strategies to address their issues. It is the responsibility of the community and all the stake holders both at micro and macro level to undertake appropriate steps by considering the problems of elderly women possibly on the following direction of -

- Bringing perceptual change in society towards old aged people not as passive receivers of care but as significant contributors to the family and society

- Having intervention on strengthening and protecting families through family enrichment programmes for the care of the elderly

- Sensitizing younger generations towards elderly women with the help of education, family life education, sensitization programmes and mass media

- Empowering younger women to help and develop them as strong elderly women in future

- Spreading awareness to elderly women about their rights and the existing governmental and nongovernmental welfare schemes for them 
- Social advocacy for the elderly to link-up them to existing welfare programmes

- Empowering them to enjoy and take benefits of these privileges meant for them

- Community sensitization and community participation programmes etc.

\section{CONCLUSION}

Women in Indian society work very hard throughout their life, dedicate every moment of life for the sake of betterment of their children and husband, and they spare their entire life and serve their family with love, care, compassion, empathy and sacrifice. But when she becomes old and needs family support, the present generation left her alone physically, socially, and psychologically. The ever-widening interaction gap between the generations is also quite responsible for the miserable condition of older women. In today's fast paced modern life younger generations hardly find few moments to share with their elders leading to loneliness and isolation issues of the elderly. Marginalization in old age is among the most common issues that are affecting the elderly women constantly. Elderly women, who live in cities, are prone to social alienation or marginalization. They find it difficult to cope with old age issues as discussed above. Due to negligence, lack of awareness, minimal financial support older women often have to face acute problems of ageing. As in most of the cases they cannot protect their rights on their own, it calls for a strong social safety net in terms of integrated programmes and social advocacy for these isolated section of the society.

\section{References:}

Balagopal, G. (2009) 'Access to health care among poor elderly women in India: how far do policies respond to women's realities?’, Gender \& Development. 17, (3), pp. 481-91.

Census of India, 2001: <www.censusindia.net>

Census of India, 2009: <www.censusindia.net>

Census of India, 2011: <www.censusindia.net>

Kumar, Vijay S. (1999) 'Quality of Life and Social Security for the Elderly in Rural India'. Council for SocialDevelopment, Hyderabad.

Prakash, I.J. (2005) 'Ageing in India: retrospect and prospect'. Bangalore University, Bangalore.

Raju, S. Siva (2002) 'Health Status of the Urban Elderly: a medico-social study,' B. R. Publishing Co., Delhi.

Raju, S. Siva (2011) 'Studies on Ageing in India: A Review', BKPAI Working Paper No. 2, United Nations Population Fund (UNFPA), New Delhi.

Report by Ministry of Statistics and Programme Implementation, 'Situation Analysis of The Elderly in India', Government of India, June, 2011 